УДК 82.09

ББК $83.3(0)+63.3(4$ Исп)61
ОТЧЕТ О МЕЖДУНАРОДНОЙ КОНФЕРЕНЦИИ «ГРАЖДАНСКАЯ ВОЙНА В ИСПАНИИ, 80 ЛЕТ СПУСТЯ. ВОСПРИЯТИЕ И ПАМЯТЬ»

(C) 2017 г. Н.Ю. Харитонова

Институт мировой литературы им. А.М. Горького Российской академии наук, Москва, Россия Национальный исследовательский университет Высшая школа экономики, Москва, Россия Дата поступления статьи: 25 октября 2016 г. Дата публикации: 25 июня 2017 г.

DOI: I0.22455/2500-4247-20I7-2-2-334-34I

Информация об авторе: Наталия Юрьевна Харитонова — Doctora en Filología Hispánica, старший научный сотрудник, Институт мировой литературы им. А.М. Горького Российской академии наук, ул. Поварская, д. 25 а, 121069 Москва, Россия.

E-mail: barrocorggu@mail.ru 


\section{INTERNATIONAL CONFERENCE "CIVIL WAR IN SPAIN, EIGHTY YEARS SINCE. PERCEPTION AND MEMORY"}

This is an open access article distributed under the Creative Commons Attribution 4.0 International (CC BY 4.0)

(C) 20I7. N.Yu. Kharitonova

A.M. Gorky Institute of World Literature of Russian Academy of Sciences, Moscow, Russia

National Research University Higher School of Economics, Moscow, Russia Received: October 25, 2016

Date of publication: June 25, 2017

Information about the author: Natalia Kharitonova, $\mathrm{PhD}$ in Hispanic Studies, Senior Researcher, A.M.Gorky Institute of the Russian Academy of Sciences, Povarskaya 25 a, I2I069 Moscow, Russia.

E-mail: barrocorggu@mail.ru 
I6 сентября 2016 г. в ИМЛИ РАН прошла международная конференция «Гражданская война в Испании, 8о лет спустя. Восприятие и память», организованная отделом литератур Европы и Америки новейшего времени. В 2016 г. отмечается годовщина начала испанской войны - трагического события, которое 8о лет назад стало информационным поводом в средствах массовой коммуникации всего мира, очень скоро превратившись в тему литературных высказываний писателей и поэтов Испании, Франции, Бельгии, Великобритании, двух Америк, СССР, Польши, Германии и многих других стран. Однако если книги воспоминаний и репортажей или романное творчество, посвященное гражданскому столкновению в Испании, изучены достаточно хорошо, то материалы литературных журналов, которые отражали происходящее в непосредственной темпоральной близости к нему или же с временной дистанции, когда отмечались годовщины событий, до сих пор не привлекали к себе внимания исследователей. Задачей конференции было изучение восприятия гражданской войны в Испании, интерпретации конфликта, рождения и функционирования интерпретационных клише, процесса формирования памяти о ней, фиксации канона, отхождения от него и трансформации темы испанской гражданской войны в мировой литературе. Основным материалом для докладов стали европейские и американские литературные журналы разного политического толка. Предметом анализа были художественные и публицистические тексты, авторство которых принадлежат литераторам, фиксировавшим непосредственные впечатления времени войны или отзывавшимся на события в Испании спустя много лет. В работе конференции приняли участие отечественные и зарубежные специалисты, молодые ученые. 
Темой первого заседания стали восприятие и интепретация испанской войны в России и США. В докладе Г.А. Филатова (Москва) были выделены и систематизированы основные направления в отечественной историографии гражданской войны в Испании, начиная І939 г. и заканчивая первым десятилетием XXI в. Основными темами ранних исследований советских историков стали военное участие Германии и Италии в гражданском конфликте, политика невмешательства и социально-экономическая политика Второй республики. Со временем спектр тем расширился, и специалисты занимались не только историей компартии Испании и ее лидеров, интернациональных бригад и политикой Коминтерна, но и внешней политикой Франко, историей испанской Фаланги и испанского фашизма. В постсоветской России открылся доступ к архивным материалам и начал формироваться более сбалансированный подход к истории испанской войны, уже лишенный прежней прокоммунистической идеологизации.

Доклад О.Ю. Пановой (Москва) был посвящен восприятию гражданской войны на страницах американского литературного журнала «Нью-Мессис». Будучи изданием левого толка, журнал был тесно связан с Советским Союзом и сразу занял сторону республиканского правительства, внимательно освещая военные события в Испании. Испанская тема стала центральной в 1936-І939 гг.: ей посвящались военные репортажи, анализы политической ситуации, статьи об испанских писателях и испанской культуре, большое количество иллюстраций с портретами испанских политических или культурных деятелей. C I937 г. ведущее место начали занимать материалы, связанные с участием американских добровольцев в войне (батальон имени Линкольна, американские летчики) и Интербригады, а также деятельностью и акциями американских организаций помощи Испании. В журнале печаталось большое количество документальных «свидетельств», в том числе американцев - участников интербригад. Также здесь появлялись стихи, посвященные гражданской войне, как американских поэтов, так и переводные. Все материалы были призваны поддержать дело Республики, осудить противника, поэтому поражение республиканцев стало трагической новостью, которая была отмечена публикацией очерка министра Республики, Хулио Альвареса дель Вайо, о последних днях в Испании.

В.Ю. Попова (Москва) обратилась к творчеству американского писателя Уолдо Фрэнка и исследовала его восприятие гражданской войны в Ис- 
пании в І936-I939 гг. и в г940-е гг. Фрэнк посвятил отдельную главу своих воспоминаний Испании и испанской гражданской войне. Интересоваться испанской темой У. Фрэнк начал еще с г920-х гг. Он дважды посещал Испанию в І92І и г924 гг., параллельно работая над книгой «Девственная Испания: эпизоды из духовной жизни великого народа». С началом гражданской войны в Испании Фрэнк не смог оставаться в стороне. В октябре г936 г. появилось его открытое письмо премьер-министру Франции Л. Блюму с призывом вести совместную борьбу против фашизма. В г937-І938 гг., особенно после поездки в Барселону, в своих статьях в испанской и американской периодике он писал об Испании как о «надежде и спасении цивилизации», по его мнению, именно благодаря Испании не только Америка, но и весь род человеческий обретали себя. В г940-х гг. У. Фрэнк вновь и вновь обращался к теме испанской гражданской войны, но в свете опыта Второй мировой войны воспоминания стали поводом для рассуждений о всеобщей вине человечества в фашизме.

Второе заседания конференции, посвященное французским литературным изданиям, открыл доклад С.Л. Фокина (Санкт-Петербург). Исследователь проанализировал видение гражданской войны в Испании в публицистике французских писателей правого толка П. Дриё ла Рошеля, P. Бразийака и М. Бланшо. Отношение интеллектуальной и литературной Франции к гражданской войне в Испании почти зеркально отражало размежевание сил в соседней стране, объятой военным конфликтом. «Испанское действие» Р. де Маэсту воспроизводило на испанской почве программу «Французского действия» Шарля Морраса. Каждый из трех французских писателей, имена которых были представлены в названии доклада, так или иначе прошли школу «Французского действия» и были знакомы с доктриной интегрального национализма, которую разрабатывал в своих трудах Моррас. Испанская гражданская война давала повод для рассуждения о судьбах Франции, представала в глазах писателей правого толка своего рода предвестием грядущей гражданской войны у себя на родине. Видение войны в Испании у Дриё ла Рошеля диктовалось элементами европейского мифа. Война в Испании для Бразильяка была конфликтом между декадансом Европы, воплотившемся в идеале мирного буржуазного благополучия, и усилением большевистской России, а в восстании Франко французский писатель увидел что-то вроде крестового похода против большевизма. Для 
Бланшо война в Испании была абсолютно чужой, он считал, что вмешательство в нее никоим образом не может пойти на пользу Франции.

Марио Мартин Хихон (Касерес, Испания) представил в своем докладе общие тенденции в освещении гражданской войны во французских изданиях культурной тематики самых разных политических взглядов: «Же суи парту», «Марианн», «Попюлер», католическую и анархистскую печать, пропагандистские проекты франкистов и республиканцев на французском языке. Беспрецедентное внимание французской печати объяснялось возможностью на примере Испании открыто решить проблемы разделенного общества своей страны. Общественное мнение во Франции менялось в зависимости от тех или иных событий. Изначально оно в большей степени определялось образами анархистской революции и свидетельствами религиозных преследований в соседней Каталонии, чем известиями о жестоких репрессиях на той территории, которую постепенно завоевывали фашисты. Но после взятия Страны Басков даже враждебные коммунизму католические издания отмежевались от франкистов. Бомбардировки Герники заставили общественное мнение повернуться в сторону республиканцев. Даже данные об участии французов в военных формированиях в Испании демонстрируют, что число французских участников Интербригад намного превышало число французов в военных формированиях сторонников мятежа.

Е.В. Дворниченко (Москва) проанализировала эволюцию взглядов французского католического писателя Ж. Бернаноса, оказавшегося свидетелем событий лета I936 г. на острове Майорка. Ученик Ш. Морраса, убежденный роялист и практикующий католик, Бернанос поначалу приветствовал франкистский переворот, однако, став свидетелем череды жестокости и насилия, написал серию статей для еженедельника «Сет», легших в основу его политико-автобиографического эссе «Большие кладбища под луной», в котором не только засвидетельствовал преступления франкистов, но и выступил с обвинением в адрес католических иерархов, прежде всего архиепископа Майоркинского, одобривших фалангистскую политику массового террора. Бернанос жестко критиковал церковь, вставшую на сторону власти и преследовавшую обездоленных, что, по его мнению, было равносильно пособничеству новому распятию Христа. Бернанос считал, что война в Испании предвещала еще более кровавые битвы в Европе, он предрек 
падение Франции в будущей войне и запечатлел картину хаоса, всеобщего страха и подозрений, воцарившихся в Европе к лету 1938 г.

Третье заседание было посвящено теме гражданской войны в Испании в литературных публикациях политических эмиграций. А.В. Добряшкина (Москва) исследовала материалы журнала немецких эмигрантов «Дас Ворт», издававшегося в 1936-г939 гг. в Москве. Период его публикации не только хронологически совпадал со временем гражданской войны в Испании, но и отражал этапы и атмосферу этой войны. Для немецких писателей-эмигрантов, публиковавшихся в журнале, война имела особое значение: лишенные возможности борьбы с нацизмом в рейхе, многие эмигрировавшие авторы принимали участие в испанских событиях: воевали или были военными журналистами. Отличительной чертой всех произведений об Испании в журнале была их тестимониальность, преобладали репортажи, короткие зарисовки, рассказы, однако постепенно произошел жанровый переход от новостного журналистского репортажа к художественному осмыслению увиденного и пережитого. В конце I938 г. была опубликована глава большого романа Германа Кестена «Дети Герники». Несмотря на то что журнал задумывался на Парижском конгрессе в защиту культуры 1935 г. как рупор внепартийного антигитлеровского сопротивления, идейной доминантой «Дас Ворт» стала именно война в Испании, что означало отождествление немецкого и испанского фашизма в восприятии немецких авторов-эмигрантов.

Н.Ю. Харитонова (Москва) раскрыла освещение темы гражданской войны в испанской версии журналов «Интернациональная литература» (1942-1945) и «Советская литература» (1946-г969). В период Великой Отечественной войны в текстах эмигрантов тема испанской войны вступила в непосредственную перекличку с темой Второй мировой. Испанцы верили в то, что победа над фашистскими режимами в Европе поставит точку в существовании режима Франко. В послевоенный период тема гражданской войны уходит со страниц журнала, задачей которого становится только продвижение советской литературы на иностранных языках, хотя большую часть работы по переводу и выпуску издания продолжали выполнять испанцы-эмигранты. Воспоминания о гражданской войне, не высказываемые прямо в публикуемых материалах, подвергались механизмам конденсации и замещения, поэтому упоминания испанских поэтов служили эквивален- 
том невысказанного переживания о войне. При этом горечь поражения, будучи табуированным мотивом, всегда трансформировалась в веру в победу испанского народа. Политические изменения в Испании, последовавшие за смертью Франко, изменения в отношениях между СССР и Испанией сняли тему борьбы с режимом, о которой писалось в течение многих десятков лет.

Ольга Глондыс (Барселона, Испания) рассказала о журнале испанских эмигрантов «Тетради конгресса за свободу культуры» (1953-I965), издававшегося в рамках самой крупной операции в области культуры, проведенной США во время Холодной войны. Конгресс оставил огромный след в культурной и политической жизни в период после Второй мировой войны, объединив самых блестящих интеллектуалов своего времени. К изданию «Тетрадей» была привлечена антифашистская и антисталинистская испанская эмиграция (Х. Горкин, Х. Маурин, В. Альба, С. де Мадарьяга, В. Кент). Тема гражданской войны в «Тетрадях» трактовалась в соответствии с политической программой журнала. Лидеры Второй республики признавались идеологическими врагами демократии, ведь во имя антифашистской борьбы они объединились с коммунистами. «Тетради» называли их виновными в установлении «тоталитарной» сталинистской «кастократии». Ряд статей расценивали роль компартии во время войны в Испании как незаконную. Политическое противостояние времен Холодной войны извлекло большую пользу из сомнений интеллектуалов в политике Народного фронта: именно антисталинизм и антикоммунизм считались в «Тетрадях» выражением приверженности демократическим ценностям.

Работа конференции позволила выявить общие направления в освещении испанской гражданской войны. Тема подвергалась значительной идеологизации, причем не только в коммунистических, но и в антикоммунистических изданиях, и это касалось как восприятия войны в I936-1939 гг., так и памяти о ней. С другой стороны, испанские события в публицистике и художественных произведениях становились источником мифологизации, поводом для рассуждений о судьбе цивилизации, размышлений о фашизме и природе насилия в целом. 